\title{
PENGARUH MODEL PEMBELAJARAN PROJECT BASED LEARNING (PjBL) TERHADAP HASIL DAN AKTIVITAS BELAJAR SISWA PADA MATERI PENCEMARAN LINGKUNGAN DI KELAS X MIA SMAN 6 BINJAI TP 2018-2019
}

\section{THE EFFECT OF PROJECT BASED LEARNING LEARNING MODELS ON STUDENT LEARNING OUTCOMES AND ACTIVITIES IN THE SUBJECT MATTER OF ENVIRONMENTAL POLLUTION CLASS X MIA SMAN 6 BINJAI TP 2018-2019}

\author{
Putri Amelia Pertiwi Pasaribu', Halim Simatupang ${ }^{2}$ \\ ${ }^{1,2}$ Program studi pendidikan Biologi, Universitas Negeri Medan, \\ J. Willem Iskandar / Pasar V, Medan, Sumatera Utara: email: putri16091997@gmail.com
}

\begin{abstract}
Abstrak
Penelitian ini bertujuan untuk mengetahui pengaruh model pembelajaran Project Based Learning terhadap hasil dan aktivitas belajar siswa pada materi pokok pencemaran lingkungan kelas X MIA SMAN 6 Binjai TP 2018-2019. Penelitian ini merupakan penelitian eksperimen dimana populasinya adalah seluruh siswa kelas $X$ MIA, Pengambilan sampel penelitian dilakukan secara acak (Random sampling). Dua kelas sebagai sampel yaitu kelas X MIA 1 sebagai kelas eksperimen yang diajar menggunakan model pembelajaran Project Based Learning dan XI MIA 2 sebagai kelas kontrol yang diajar menggunakan problem based learning. Kelas eksperimen berjumlah 35 orang dan kelas kontrol berjumlah 29 orang, sehingga jumlah keseluruhan sebanyak 62 orang. Rata-rata hasil belajar kelas eksperimen sebesar 82,43 dan kelas kontrol 75,69. Uji hipotesis menunjukkan bahwa perhitungan thitung $\geq \mathrm{t}_{\text {tabel }}(3,404 \geq 1,999)$ yang berarti $\mathrm{H}_{\mathrm{a}}$ diterima dan $\mathrm{H}_{0}$ ditolak. Maka, disimpulkan bahwa ada pengaruh hasil belajar siswa yang diajarkan dengan model pembelajaran Project Based Learning $(\mathrm{PjBL})$. Untuk perhitungan aktivitas belajar siswa diperoleh rata-rata nilai aktivitas belajar siswa pada kelas eksperimen (89) lebih tinggi dibanding niali rata-rata kelas kontrol $(65,4)$. Uji hipotesis menunjukkan thitung $\geq$ tabel $(3,48 \geq 1,99)$, maka dinyatakan Hoditolak dan $\mathrm{H}_{\mathrm{a}}$ diterima. Dengan demikian ada pengaruh model pembelajaran Project Based Learning terhadap aktivitas belajar siswa. Maka dari itu, dapat dapat disimpulkan bahwa ada pengaruh model pembelajaran Project Based Learning terhadap hasil dan aktivitas belajar siswa pada materi pencemaran lingkungan di kelas X MIA SMAN 6 Binjai TP 2018-2019.
\end{abstract}

Kata kunci : Project Based Learning, Hasil dan Aktivitas Belajar, Pencemaran Lingkungan

\begin{abstract}
This study aims to determine the effect of Project Based Learning learning models on student learning outcomes and activities in the subject matter of environmental pollution class X MIA SMAN 6 Binjai TP 20182019. This research is an experimental research where the population is all students of class $X$ MIA. The sampling is done randomly. The two classes as samples were class X MIA 1 as the experimental class which was taught using the Project Based Learning model and XI MIA 2 as the control class taught by using problem based learning. The experimental class is 35 people and the control class is 29 people, so the total number is 62 people. The average learning outcomes of the experimental class amounted to 82.43 and the control class 75.69. Hypothesis testing shows that the calculation of $t$ count abel $t$ table $(3.404 \geq 1.999)$ which means $\mathrm{H}_{a}$ is accepted and $\mathrm{H}_{0}$ is rejected. So, it was concluded that there was an effect of student learning outcomes taught with the Project Based Learning ( $\mathrm{PjBL}$ ) learning model. For the calculation of student learning activities, the average value of student learning activities in the experimental class (89) is higher than the mean of the control class (65.4). Hypothesis test shows $t$ count abel $t$ table $(3.48 \geq 1.99)$, then $\mathrm{H}_{0}$ is rejected and $\mathrm{H}_{\mathrm{a}}$ is accepted. Thus there is the influence of the Project Based Learning learning model on student learning activities. Therefore, it can be concluded that there is the influence of the Project Based Learning learning model on student learning outcomes and activities in environmental pollution material in class X MIA SMAN 6 Binjai TP 2018-2019.
\end{abstract}

Key Words : Project Based Learning, Learning Result and Activity, Enviromental Pollution 
Hal : $10-x x x$

\section{Pendahuluan}

Biologi adalah salah satu cabang sains yang besar peranannya dalam kehidupan, terlebih dalam bidang ilmu pengetahuan dan teknologi (IPTEK) yang berkembang dengan pesat saat ini. Biologi tidak hanya memberikan sumbangan yang nyata terhadap perkembangan teknologi melainkan juga mendidik siswa untuk memiliki sikap intelektual dan religi dalam kehidupan. Oleh karena itu siswa dituntut untuk hanya mampu dalam hal pengetahuan, tetapi juga harus terampil dan memiliki sikap yang baik dalam menghadapi perubahan dalam segala bidang, berpikir kreatif, kritis, aktif, dan inovatif.

Pernyataan tersebut sesuai dengan pendapat [7], pembelajaran biologi hendaknya diterapkan sesuai dengan hakikat biologi sebagai sains meliputi mids of (kognitif), hearts on (afektif) dan hands on (psikomotor). Untuk mencapai keberhasilan belajar tersebut, maka diperlukan model pembelajaran yang bervariasi untuk menarik minat belajar peserta didik. Model pembelajaran adalah suatu perencanaan atau suatu pola yang digunakan sebagai pedoman dalam merencanakan pembelajaran di kelas. Pada kurikulum 2013 telah memberikan acuan dalam pemilihan model pembelajaran yang sesuai dengan pendekatan saintifik. Model pembelajaran yang dimaksud meliputi : Project Based Learning (PjBL), Problem Based Learning (PBL),atau Discovery Learning. Pemilihan model pembelajaran diserahkan kepada guru dengan menyesuaikan dengan karakteristik materi ajar [1].

Pembelajaran berbasis proyek merupakan model pembelajaran yang dapat membantu siswa membangun pemikirannya dan keterampilan berkomunikasi. Pembelajaran berbasis proyek atau Project Based Learning memiliki langkah : Planning (perencanaan), Creating (implementasi) dan Processing (pengolahan). Project Based Learning dapat membantu siswa dalam belajar kelompok, mengembangkan keterampilan yang dimiliki dan proyek yang dikerjakan mampu memberikan pengalaman secara pribadi kepada siswa juga menekankan kegiatan belajar yang berpusat pada siswa. Dengan demikian guru tidak lagi berperan sebagai sumber belajar melainkan sebagai fasilitator, artinya guru lebih banyak membantu siswa untuk belajar, guru juga memonitoring siswa pada saat belajar.

Namun, penerapan pembelajaran biologi sesuai hakikatnya sebagai sains belum dapat sepenuhnya diterapkan di Indonesia. Hasil penelitian menunjukkan bahwa negara-negara Asia Tenggara masih banyak yang menggunakan paradigma Teacher Centered dengan menggunakan pendekatan ceramah deduktif dan masih jarang yang menerapkan paradigma Students Centered atau Process Oriented Approach [5].

Masalah itu dapat diatasi dengan suatu model pembelajaran yang bisa mengubah aktivitas yang pasif menjadi aktif. Meningkatnya aktivitas siswa dapat menambah pengetahuan siswa dari pengalaman baru yang telah dilakukannya. Salah satu model pembelajaran yang dimaksud adalah Project Based Learning.

Pada materi pencemaran lingkungan siswa hanya mengetahui konsep teori tanpa mengetahui solusi yang dapat dilakukan ketika menghadapi masalah di lingkungan sekitar. Seperti halnya dengan masalah kebersihan lingkungan kita ini, Kementrian Lingkungan Hidup dan Kehutanan Republik Indonesia (KLHKRI) telah merilis daftar Kota di Indonesia berdasarkan tingkat kebersihannya, Kota Medan terpuruk di urutan terkotor untuk kategori kota metropolitan. Itu menjadi salah satu bukti, kurang pedulinya masyarat terhadap lingkungan sekitar, dan Project Based Learning adalah model yang tepat untuk digunakan pada materi pencemaran lingkungan untuk mendorong ide kreatif, aktivitas belajar dan kerja sama siswa dalam menjalankan suatu proyek yang diharapkan mampu meningkatkan sikap peduli terhadap kebersihan lingkungan sekitar.

Berdasarkan uraian di atas, maka dapat dilakukan penelitian dengan judul : " Pengaruh Model Pembelajaran Project Based Learning terhadap Hasil dan Aktivitas Belajar Siswa Pada Materi Pencemaran Lingkungan Di Kelas X MIA SMAN 6 Binjai TP 2018-2019".

\section{Metode Penelitian}

Penelitian ini adalah penelitian eksperimen sungguhan menggunakan desain penelitian pretest and postest group design. Sampel dalam penelitian ini adalah siswa kelas X MIA 1 sebagai kelas eksperimen menggunakan model Project Based Learning dan X MIA 2 sebagai kelas kontrol menggunakan model Problem Based Learning. Teknik pengambilan sampel menggunakan teknik simple random sampling. Teknik pengumpulan data dengan menggunakan tes berupa pertanyaan pilihan berganda untuk memperoeh nilai kognitif siswa. Tes yang digunakan sebelumnya dilakukan uji instrumen yang meliputi validitas, reliabilitas, taraf kesukaran soal dan daya beda soal menggunakan SPSS version 20 Dan untuk mengetahui aktivitas siswa menggunakan lembar observasi dengan bantuan observer. Kemudian data tersebut dianalisis menggunakan 
Hal : $10-x x x$

program SPSS version 20yang meliputi uji normalitas dan uji homogenitas sebelum dilakukan uji hipotesis dengan menggunakan Uji-t.

\section{Hasil Penelitian dan Pembahasan}

\section{Hasil Penelitian \\ Pengaruh Model Pembelajaran Project Based Learning Terhadap Hasil Belajar Siswa Pada Materi Pencemaran Lingkungan}

Hasil belajar kognitif siswa diukur dengan melakukan pretest dan postest. Pretest bertujuan untuk mengetahui kemampuan awal siswa sebelum dilakukan kegiatan pembelajaran, sedangkan postest bertujuan untuk mengetahui hasil belajar siswa setelah dilakukan kegiatan pembelajaran. Perbedaan nilai pretest pada kedua kelas dapat dilihat pada Tabel 1.

Tabel 1. Perbandingan Nilai Pretest Siswa

\begin{tabular}{|c|c|c|c|c|c|c|c|}
\hline \multicolumn{4}{|c|}{ Kelas Project based learning } & \multicolumn{4}{|c|}{ Kelas Kontrol } \\
\hline Nilai & $\mathbf{F}$ & $\bar{X}$ & SD & Nilai & $\mathbf{F}$ & $\bar{X}$ & SD \\
\hline 20 & 1 & \multirow{10}{*}{43,86} & \multirow{10}{*}{11,94} & 20 & 2 & \multirow{10}{*}{40,52} & \multirow{10}{*}{14,41} \\
\hline 25 & 3 & & & 25 & 4 & & \\
\hline 30 & 2 & & & 30 & 4 & & \\
\hline 35 & 5 & & & 35 & 3 & & \\
\hline 40 & 5 & & & 40 & 4 & & \\
\hline 45 & 4 & & & 45 & 3 & & \\
\hline 50 & 7 & & & 50 & 5 & & \\
\hline 55 & 3 & & & 55 & 1 & & \\
\hline 60 & 4 & & & 60 & 1 & & \\
\hline 70 & 1 & & & 75 & 2 & & \\
\hline Jumlah & 35 & & & Jumlah & 29 & & \\
\hline
\end{tabular}

Dari tabel 1, dapat diketahui frekuensi nilai pretest pada kelas eksperimen dan kelas kontrol. Dari hasil perhitungan pretest diperoleh nilai rata-rata pretest siswa kelas yang diajarkan dengan menggunakan model pembelajaran Project Based Learning sebesar 43,86 sedangkan nilai rata-rata pretest kelas kontroldengan model problem based learning sebesar 40,52. Dapat dilihat bahwa selisih nilai antara kelas eksperimen dan kelas kontrol tidak jauh berbeda. Maka dari itu, tidak terdapat perbedaan pada kemampuan awal siswa pada kelas eksperimen dan kelas kontrol. Dan untuk mengetahui data perolehan nilai pretest pada kelas kontrol dan eksperimen dari masing-masing indikator kognitifnya dapat dilihat pada Gambar 1.

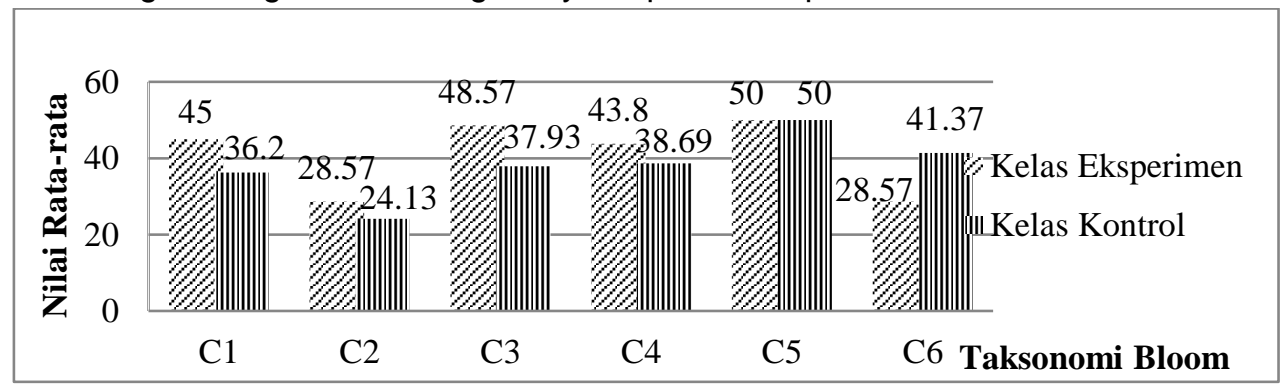

Gambar 1. Diagram batang perolehan masing-masing indikator nilai kognitif pretestpada kelas kontrol dan eksperimen kelas X MIA SMAN 6 Binjai TP. 2018-2019.

Dari keenam aspek Taksonomi Bloom pada Gambar 1, terlihat bahwa nilai pretest tertinggi yaitu pada aspek C5 (Mengevaluasi) dengan nilai 50, dimana kelas kontrol dan eksperimen memperoleh nilai yang sama pada aspek tersebut. Dan nilai kognitif terendah saat pretest adalah sebesar 24,13 pada aspek C2 (Memahami) pada kelas kontrol. Sedangkan pada kelas eksperimen nilai kognitif terendah saat pretest yaitu pada aspek C2 (Memahami) dan C6 (Mengkreasikan) dengan nilai 28,57. 
Tabel 2. Perbandingan Nilai Post-Test Siswa

\begin{tabular}{|c|c|c|c|c|c|c|c|}
\hline \multicolumn{4}{|c|}{ Kelas Project based learning } & \multicolumn{4}{|c|}{ Kelas Kontrol } \\
\hline Nilai & $\mathbf{F}$ & $\bar{X}$ & SD & Nilai & $\mathbf{F}$ & $\bar{X}$ & SD \\
\hline 60 & 1 & \multirow{9}{*}{82,43} & \multirow{9}{*}{7,16} & 60 & 1 & \multirow{9}{*}{75,69} & \multirow{9}{*}{9,10} \\
\hline 65 & 1 & & & 65 & 3 & & \\
\hline 70 & 3 & & & 70 & 5 & & \\
\hline 75 & 5 & & & 75 & 8 & & \\
\hline 80 & 7 & & & 80 & 7 & & \\
\hline 85 & 6 & & & 85 & 4 & & \\
\hline 90 & 7 & & & 90 & 1 & & \\
\hline 95 & 5 & & & & & & \\
\hline Jumlah & 35 & & & Jumlah & 29 & & \\
\hline
\end{tabular}

Dari Tabel 2 dapat diketahui frekuensi nilai postest pada kelas eksperimen dan kelas kontrol. Dari hasil perhitungan postest diperoleh nilai rata-rata postest siswa kelas yang diajarkan dengan menggunakan model pembelajaran Project Based Learning sebesar 82,43 sedangkan nilai rata-rata postestkelas kontroldengan model problem based learning sebesar 75,69. Dapat dilihat bahwa selisih nilai antara kelas eksperimen dan kelas kontrol jauh berbeda. Dan untuk mengetahui data perolehan nilai postest pada kelas kontrol dan eksperimen dari masing-masing indikator kognitifnya dapat dilihat pada gambar 2.

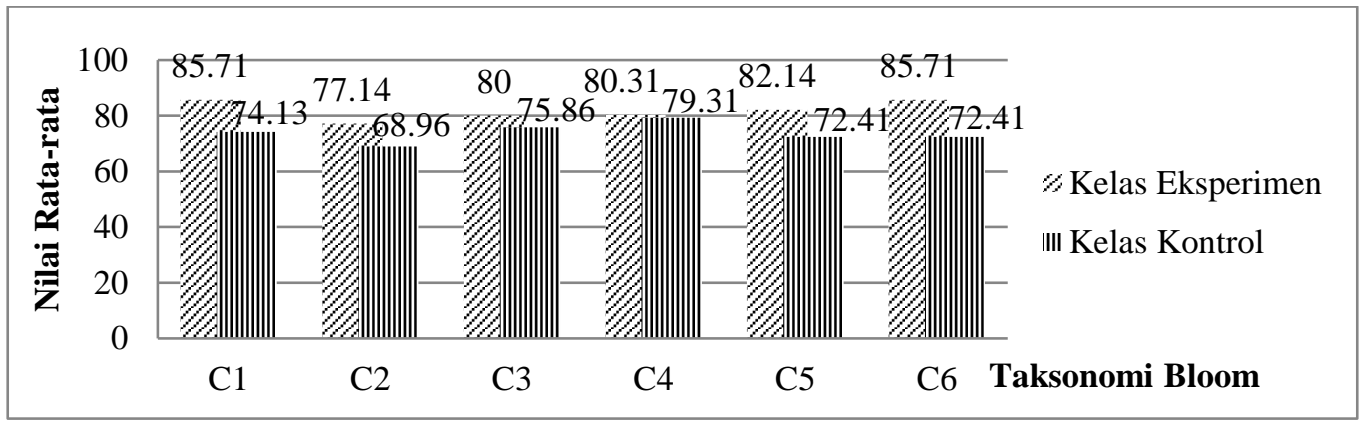

Gambar 2. Diagram batang perolehan masing-masing indikator nilai kognitif postest pada kelas kontrol dan eksperimen kelas X MIA SMAN 6 Binjai TP. 2018-2019.

Dari keenam aspek Taksonomi Bloom pada Gambar 4.2, terlihat bahwa rata-rata nilai postest tertinggi pada kelas eksperimen yaitu C1( Mengingat) dan C6 (Mengkreasikan) dengan nilai 85,71. Dan nilai terendah pada kelas eksperimen adalah C2 (Memahami) dengan nilai 77, 14. Sedangkan kelas kontrol aspek kognitif tertinggi pada C4 ( Menganalisis) dengan nilai 79,31 dan aspek kognitif terendah pada C2 (Memahami) dengan nilai 68,96 .

\section{Uji-t Model Pembelajaran Project Based Learning Terhadap Hasil}

\section{Belajar Siswa Pada Materi Pencemaran Lingkungan}

Setelah dilakukan uji prasyarat analisis data, diketahui bahwa data hasil belajar kedua kelompok pada penelitian ini berdistribusi normal dan homogen, sehingga dilanjutkan dengan uji hipotesis ( uji-t) untuk mengetahui pengaruh dari model pembelajaran Project Based Learning yang diajarkan di kelas eksperimen. Dari hasil uji hipotesis (uji-t) diperoleh data pada Tabel 3.

Tabel 3. Perhitungan Uji-t Hasil Belajar Siswa

\begin{tabular}{c|c|c|c|c|c}
\hline No & $\begin{array}{c}\text { Model } \\
\text { Pembelajaran }\end{array}$ & $\begin{array}{c}\text { Rata-Rata } \\
\text { Nilai } \\
\text { Postest }\end{array}$ & $\mathbf{T}_{\text {hitung }}$ & $\mathbf{T}_{\text {tabel }}$ & Kesimpulan \\
\hline
\end{tabular}


Hal : $10-x x x$

\begin{tabular}{c|c|c|c|c|l}
\hline 1 & Kelas PjBL & 82,43 & \multirow{2}{*}{3,40} & 1,99 & $\begin{array}{l}\text { Ada pengaruh model } \\
\text { pembelajaran Project Based } \\
\text { Learning terhadap hasil } \\
\text { belajar siswa pada materi } \\
\text { pencemaran lingkungan di } \\
\text { kelas X MIA SMAN 6 Binjai } \\
\text { TP 2018-2019. }\end{array}$ \\
\hline 2 & Kelas Kontrol & 75,69 &
\end{tabular}

Dari hasil perhitungan uji hipotesis (pada lampiran 17) diperoleh thitung $=3,404$. Harga tabel pada $\mathrm{dk}=$ $(n 1+n 2)-2=(35+29)-2=62$ dan taraf signifikansi $\alpha=0,05$ tidak terdaftar dalam daftar, maka dicari dengan menggunakan distribusi $t$ dengan interpolasi, sehingga diperoleh $t_{\text {tabel }}=1,99$. Ternyata thitung $\geq t_{\text {tabel }}(3,40 \geq$ 1,99), maka dinyatakan $\mathrm{H}_{0}$ ditolak dan $\mathrm{H}_{\mathrm{a}}$ diterima, $\mathrm{H}_{\mathrm{a}}$ berarti ada pengaruh model pembelajaran Project Based Learningterhadap hasil belajar siswa pada materi pencemaran lingkungan di kelas X MIA SMAN 6 Binjai TP 2018-2019.

\section{Pengaruh Model Pembelajaran Project Based Learning Terhadap Aktivitas Belajar Siswa Pada Materi Pencemaran Lingkungan}

Aktivitas siswa dinilai berdasarkan empat indikator, a). ketepatan pemecahan masalah atau ide dinilai berdasarkan ide yang diberikan masing-masing kelompok di lembar LKPD yang telah disediakan, b). Keterampilan mengerjakan tugas dinilai berdasarkan aspek yang telah ditentukan selama pembuatan proyek berlangsung, c). Keterampilan berdiskusi dinilai berdasarkan aspek yang telah ditentukan selama proses diskusi berlangsung, d). Keterampilan menyajikan hasil dinilai berdasarkan aspek yang telah ditentukan selama proses presentasi berlangsung. Keempat indikator tersebut dinilai berdasarkan deskriptor yang ada. Penilaian aktivitas dilakukan secara kelompok. Pada kelas eksperimen dibagi menjadi 5 kelompok, dimana masingmasing kelompok beranggotakan 7 siswa. Sedangkan pada kelas kontrol dibagi menjadi 5 kelompok dimana masing-masing kelompok beranggotakan 5-6 siswa. Berdasarkan pengamatan yang dilakukan pada saat penelitian, diperoleh aktivitas siswa pada kelas eksperimen pada Tabel 4.

Tabel 4. Perhitungan Aktivitas Belajar Siswa Kelas Eksperimen

\begin{tabular}{|c|c|c|c|c|c|c|c|c|}
\hline \multirow[b]{2}{*}{ No } & \multirow[b]{2}{*}{ Indikator yang diamati } & \multicolumn{7}{|c|}{ Kelas Eksperimen } \\
\hline & & $\begin{array}{c}\text { Kel. } \\
1\end{array}$ & Kel. 2 & $\begin{array}{c}\text { Kel. } \\
3\end{array}$ & $\begin{array}{c}\text { Kel. } \\
4\end{array}$ & $\begin{array}{c}\text { Kel. } \\
5\end{array}$ & $\begin{array}{l}\text { Skor } \\
\text { Total }\end{array}$ & Nilai \\
\hline 1 & $\begin{array}{l}\text { Ketepatan pemecahan } \\
\text { masalah atau ide }\end{array}$ & 4 & 4 & 3 & 3 & 4 & 18 & 90 \\
\hline 2 & $\begin{array}{l}\text { Keterampilan } \\
\text { Mengerjakan Tugas }\end{array}$ & 4 & 3 & 4 & 3 & 4 & 18 & 90 \\
\hline 3 & $\begin{array}{l}\text { Keterampilan } \\
\text { Berdiskusi }\end{array}$ & 4 & 4 & 4 & 3 & 4 & 19 & 95 \\
\hline 4 & $\begin{array}{l}\text { Keterampilan } \\
\text { Menyajikan Hasil }\end{array}$ & 3 & 3 & 3 & 3 & 4 & 16 & 80 \\
\hline \multicolumn{2}{|r|}{ Skor Total } & 15 & 14 & 14 & 12 & 16 & & \\
\hline \multirow{2}{*}{\multicolumn{2}{|c|}{$\begin{array}{c}\text { Nilai } \\
\text { Rata-Rata } \\
\end{array}$}} & 94 & 88 & 88 & 75 & 100 & & \\
\hline & & \multicolumn{5}{|c|}{89} & & \\
\hline
\end{tabular}

Berdasarkan Tabel 4 diperoleh nilai rata-rata aktivitas belajar siswa kelas eksperimen yang menggunakan model pembelajaran Project Based Learning adalah 89 dengan kategori Sangat Aktif pada skala penilaian aktivitas siswa. Selain itu, dari tabel di atas juga diperoleh pencapaian nilai masing-masing indikator, nilai keterampilan berdiskusi adalah 95 dengan kategori Sangat Aktif, nilai indikator ketepatan pemecahan masalah dan nilai keterampilan mengerjakan tugas adalah 90 dengan kategori Sangat Aktif, dan nilai keterampilan menyajikan hasil adalah 80 dengan kategori Aktif. Selanjutnya perhitungan aktivitas belajar siswa pada kelas kontrol dapat dilihat pada Tabel 5.Berdasarkan Tabel 5, diperoleh nilai rata-rata aktivitas belajar siswa kelas kontrol yang menggunakan pendekatan saintifik adalah 65,4 dengan kategori Cukup Aktif pada skala penilaian aktivitas siswa. 
Hal : $10-17$

Tabel 5. Perhitungan Aktivitas Belajar Siswa Kelas Kontrol

\begin{tabular}{|c|c|c|c|c|c|c|c|c|}
\hline \multirow[b]{2}{*}{ No } & \multirow[b]{2}{*}{ Indikator yang diamati } & \multicolumn{7}{|c|}{ Kelas Kontrol } \\
\hline & & $\begin{array}{c}\text { Kel. } \\
1\end{array}$ & Kel. 2 & $\begin{array}{c}\text { Kel. } \\
3\end{array}$ & $\begin{array}{c}\text { Kel. } \\
4\end{array}$ & $\begin{array}{c}\text { Kel. } \\
5\end{array}$ & $\begin{array}{l}\text { Skor } \\
\text { Total }\end{array}$ & Nilai \\
\hline 1 & $\begin{array}{l}\text { Ketepatan pemecahan } \\
\text { masalah atau ide }\end{array}$ & 2 & 2 & 2 & 2 & 2 & 10 & 50 \\
\hline 2 & $\begin{array}{l}\text { Keterampilan } \\
\text { Mengerjakan Tugas }\end{array}$ & 2 & 2 & 2 & 2 & 2 & 10 & 50 \\
\hline 3 & Keterampilan Berdiskusi & 4 & 3 & 3 & 3 & 3 & 16 & 80 \\
\hline 4 & $\begin{array}{l}\text { Keterampilan } \\
\text { Menyajikan Hasil }\end{array}$ & 3 & 3 & 4 & 3 & 3 & 16 & 80 \\
\hline & Skor Total & 11 & 10 & 11 & 10 & 10 & & \\
\hline & Nilai & 69 & 63 & 69 & 63 & 63 & & \\
\hline & Rata-Rata & & & 65,4 & & & & \\
\hline
\end{tabular}

Selain itu, dari tabel di atas juga diperoleh pencapaian nilai masing-masing indikator, nilai keterampilan berdiskusi dan nilai keterampilan menyajikan hasil adalah 80 dengan kategori Aktif, dan nilai indikator ketepatan pemecahan masalah dan nilai keterampilan mengerjakan tugas adalah 50 dengan kategori Kurang Aktif, data tersebut dapat dilihat dalam bentuk diagaram pada Gambar 3.

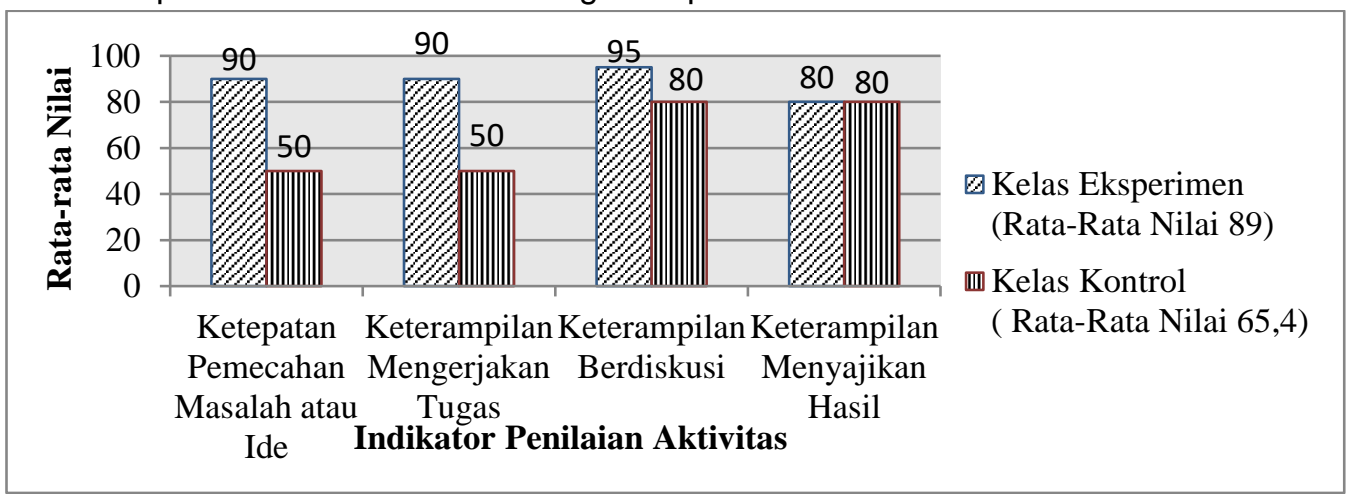

Gambar 3. Diagram batang perbedaan nilai aktivitas belajar berdasarkan indikator pada kelas ekperimen dengan kelas kontrol pada materi Pencemaran Lingkungan di kelas X MIA SMAN 6 Binjai TP. 2018-2019.

Dari gambar 4.3 dapat diketahui bahwa nilai indikator keterampilan berdiskusi sebesar 95 dengan kategori Sangat Aktif dan pada kelas kontrol memperoleh nilai sebesar 80 dengan kategori Aktif. Lalu, indikator ketepatan pemecahan masalah dan keterampilan mengerjakan tugas pada kelas eksperimen diperoleh nilai sebesar 90 dengan kategori Sangat Aktif sedangkan kelas kontrol memperoleh nilai sebesar 50 dengan kategori Kurang Aktif, dan pada indikator keterampilan menyajikan hasil pada kelas eksperimen dan kelas kontrol memperoleh nilai sebesar 80 dengan kategori Aktif.

Uji-t Model Pembelajaran Project Based Learning Terhadap Aktivitas Belajar Siswa Pada Materi Pencemaran Lingkungan

Untuk mengetahui pengaruh model pembelajaran Project Based Learning terhadap aktivitas belajar siswa, maka dilakukan uji t pada nilai aktivitas siswa. Dari hasil uji hipotesis (uji-t), diperoleh data pada Tabel 6.

Tabel 6. Perhitungan Uji-t Aktivitas Belajar Siswa

\begin{tabular}{c|c|c|c|c|c|}
\hline No & $\begin{array}{c}\text { Model } \\
\text { Pembelajaran }\end{array}$ & $\begin{array}{c}\text { Rata-Rata } \\
\text { Nilai } \\
\text { Postest }\end{array}$ & $\mathbf{T}_{\text {hitung }}$ & $\mathbf{T}_{\text {tabel }}$ & \multicolumn{2}{|c}{ Kesimpulan } \\
\hline 1 & Kelas PjBL & 89 & 3,48 & 1,99 & $\begin{array}{l}\text { Ada pengaruh model } \\
\text { pembelajaran Project Based } \\
\text { Learning terhadap aktivitas } \\
\text { belajar siswa pada materi }\end{array}$ \\
\hline
\end{tabular}




\begin{tabular}{l|l|l|l|l}
\hline & & & & $\begin{array}{l}\text { Pencemaran Lingkungan di } \\
\text { kelas X MIA SMAN 6 TP. } \\
2018-2019 .\end{array}$ \\
\hline
\end{tabular}

Dari hasil perhitungan uji hipotesis (pada lampiran 17) diperoleh thitung $=3,480$. Harga tabel pada $\mathrm{dk}=$ $(n 1+n 2)-2=(35+29)-2=62$ dan taraf signifikansi $\alpha=0,05$ tidak terdaftar dalam daftar, maka dicari dengan menggunakan distribusi $t$ dengan interpolasi, sehingga diperoleh tabel $=1,99$. Ternyata thitung $\geq t_{\text {tabel }}(3,48 \geq$ 1,99), maka dinyatakan $\mathrm{H}_{0}$ ditolak dan $\mathrm{H}_{\mathrm{a}}$ diterima, $\mathrm{H}_{\mathrm{a}}$ berarti ada pengaruh model pembelajaran Project Based Learningterhadap aktivitas belajar siswa pada materi pencemaran lingkungan di kelas X MIA SMAN 6 Binjai TP 2018-2019.

\section{Pembahasan}

Setelah menganalisis nilai postest pada kelas eksperimen dan kelas kontrol, diperoleh nilai rata-rata kelas eksperimen yang menggunakan Project Based Learning lebih meningkat. Selanjutnya dilakukanuji hipotesis hasil belajar atau postest untuk mengetahui ada atau tidaknya pengaruh dari model yang diberikan pada kelas eksperimen. Uji hipotesis ini menggunakan uji-t. Setelah dilakukan pengujian data, diperoleh hasil perhitungan yang menyatakan bahwa thitung $\geq t_{\text {tabel }}$ yang berarti $\mathrm{H}_{\mathrm{a}}$ diterima dan $\mathrm{H}_{0}$ ditolak, $\mathrm{H}_{\mathrm{a}}$ berarti ada pengaruh model pembelajaran Project Based Learning terhadap hasil belajar siswa. Adanya pengaruh hasil belajar pada kelas eksperimen disebabkan oleh model pembelajaran yang diterapkan pada kelas eksperimen lebih menuntut siswa untuk bisa memilih, merancang dan memimpin pikiran serta pekerjaannya sendiri sehingga siswa dapat mengaplikasikan cara pelestarian lingkungan dengan penanganan limbah. Aspek kognitif berdasarkan Taksonomi Bloom yang tertinggi di kelas eksperimen adalah pada aspek C1 (Memahami) dan C6 (Mengkreasikan), hal tersebut membuktikan bahwa model Project Based Learning dapat berpengaruh terhadap pengetahuan dan kreasi siswa karena model Project Based Learning membuat siswa untuk membangun pengetahuannya sendiri dalam memecahkan masalah kerusakan lingkungan dengan keterampilan menganalisis faktor penyebab terjadinya kerusakan lingkungan, membuat produk sampai mempresentasikan produk pembelajaran berdasarkan pengalaman nyata dengan membuat sebuah daur ulang limbah yang bermanfaat. Sedangkan pada kelas kontrol nilai tertingi pada aspek $\mathrm{C} 4$, hal tersebut disebabkan oleh model yang digunakan pada kelas kontrol kurang menuntut siswa untuk mengevaluasi dan mengkreasikan suatu pembelajaran sehingga mereka hanya memahami teori tanpa paham pengaplikasian teori tersebut.

Perbedaan hasil belajar pada kelas eksperimen dan kontrol disebabkan oleh kelas yang menggunakan model pembelajaran project based learning mampu memecahkan masalah dengan memberikan suatu produk sebagai solusi dari masalah tersebut sehingga siswa dapat mengaplikasikan teori yang dipelajari, pada proses pengaplikasian teori tersebut membuat siswa lebih memahami teori yang telah dipelajari, sedangkan kelas kontrol yang menggunakan problem based learning hanya melakukan diskusi biasa tanpa ada proyek yang dihasilkan.

Hasil penelitian tersebut senada dengan hasil penelitian yang dilakukan Mukra dan Nasution (2016), menyatakan bahwa hasil belajar menggunakan model project based learning meningkat dibandingkan model pembelajaran problem based learning, karena project based learning dapat meningkatkan kemampuan pemecahan masalah dan keterampilan dalam memberikan solusi pada suatu masalah. Peneliti lainnya yaitu Insyasiska, dkk (2015) menyatakan bahwa nilai kognitif yang menggunakan model pembelajaran project based learning meningkat karena siswa dapat mengaplikasikan teori yang sudah diajarkan.

Aktivitas siswa dinilai berdasarkan empat indikator yaitu, ketepatan pemecahan masalah atau ide, keterampilan membuat proyek, keterampilan berdiskusi dan keterampilan menyajikan hasil. Dari keempat indikator tersebut memiliki nilai yang berbeda pada setiap kelompok, karena aktivitas tiap kelompok dinilai dengan menyesuaikan dengan deskriptor yang ada. Untuk rata-rata nilai aktivitas belajar siswa, kelas eksperimen memperoleh nilai lebih tinggi dengan kategori sangat aktif, dibandingkan nilai pada kelas kontrol dengan kategori cukup aktif. Selanjutnya, nilai aktivitas belajar siswa dilakukan uji hipotesis untuk mengetahui pengaruh model pembelajaran PjBL terhadap aktivitas belajar siswa (uji-t), dimana thitung $\geq$ tabelmaka dinyatakan Hoditolak dan $\mathrm{H}_{\mathrm{a}}$ diterima, Haditerima berartiada pengaruh model pembelajaran Project Based Learning terhadap aktivitas belajar siswa pada materi pencemaran lingkungan di kelas X MIA SMAN 6 Binjai TP 2018-2019. 
Hal : $10-x x x$

Dari keempat indikator tersebut, diperoleh rata-rata nilai aktivitas belajar siswa pada kelas eksperimen lebih tinggi, hal tersebut disebabkan oleh kelas eksperimen lebih dituntut untuk menyelesaikan masalah dengan berdasarkan pengalaman nyata dengan menghasilkan suatu produk, sedangkan kelas kontrol hanya berdiskusi biasa dalam menyelesaikan masalah tersebut. Hasil penelitian ini selaras dengan hasil penelitian Yulianto, dkk (2017), model Project Based Learning dapat meningkatkan keaktifan belajar siswa dan dapat memberikan pengalaman baru terhadap siswa dan guru bidang studi. Penelitian lainnya yang selaras dengan hasil penelitian ini yaitu hasil penelitian Rezeki, dkk (2015), model pembelajaran Project Based Learning (PjBL) dapat meningkatkan aspek kognitif dan aktivitas belajar siswa karena PjBL menunjukkan keterlibatan yang tinggi pada semua siswa, kekompakan serta kepercayaan diri yang meningkat.Berdasarkan hasil penelitian tersebut dapat disimpulkan bahwa penerapan model pembelajaran Project Based Learning berpengaruh terhadap aktivitas belajar siswa, dimana aktivitas belajar siswa juga dapat mempengaruhi hasil belajar siswa.

\section{Kesimpulan}

Berdasarkan hasil uji hipotesis yang dilakukan, maka disimpulkan bahwa ada pengaruh model pembelajaran Project Based Learning (PjBL) terhadap hasil dan aktivitas belajar siswa pada materi pencemaran lingkungan di kelas X MIA SMAN 6 Binjai TP. 2018-2019.

\section{Daftar Pustaka}

[1] Afriana., Permana., Fitriani., (2016), Penerapan Project Based Learning Terintegrasi STEM untuk Meningkatkan Literasi Sains Siswa Ditinjau dari Gender, Jurnal Inovasi Pendidikan IPA, 2(2) : 202-212.

[2] Insyasiska., Zubaidah., Susilo., (2015), Pengaruh Project Based Learning Terhadap Motivasi Belajar, Kreativitas, Kemampuan Berpikir Kritis, dan Kemampuan Kognitif Siswa Pada Pembelajaran Biologi, Jurnal Pendidikan Biologi, 7(1),9-21.

[3] Knutsson., (2010), Reality Based Learning, How to get Business Students Down to Bussiness. International Journal of Teaching and Learning in Higher Education, 22(3), 277-286.

[4] Mukra., Nasution, Y., (2016), Perbedaan Hasil Belajar Siswa Menggunakan Model Project Based Learning Dengan Problem Based Learning Pada Materi Pencemaran dan Pelestarian Lingkungan Hidup, Jurnal Pelita Pendidikan, 4(2), 122-127.

[5] Noor, A., (2007), Teaching Thingking Skill Redesigning Classroom Pratices, Universitas Brunei Darussalam.

[6] Rezeki., Nurhayati., Mulyani., (2015), Penerapan Project Based Learning Disertai Peta Konsep dalam Meningkatkan Prestasi dan Aktivitas Belajar, Jurnal Pendidikan, 4(1), 74-81.

[7] Rustaman, N., (2005), Strategi Belajar Mengajar Biologi, Malang, UNM Press.

[8] Yulianto., Fatchan., Astina., (2017), Penerapan Model Pembelajaran Project Based Learning Berbasis Lesson Study Untuk Meningkatkan Keaktifan Belajar Siswa, Jurnal Pendidikan, 2(3), 448-453 
